\title{
INTRODUCTION TO THE SYMPOSIUM ON GREGORY SHAFFER, "GOVERNING THE INTERFACE OF U.S.-CHINA TRADE RELATIONS"
}

\author{
Harlan Grant Cohen*
}

What happens to international institutions when expectations about their function and purpose shift? Must such institutions give way as states reconsider the settlements on which those institutions are based, or can they adapt (or be adapted) to new geopolitical realities? Or to put it most bluntly, as the geopolitical balance of power shifts, must law give way to power? At a very deep level, these are the questions animating Gregory Shaffer's "Governing the Interface of U.S.-China Trade Relations," published in the American Journal of International Law. ${ }^{1}$ As the ballooning rivalry between the United States and China stretches and strains institutions like the World Trade Organization (WTO), Shaffer remains committed to the idea that law can help manage interstate relationships, contain disagreements, and even maintain the peace. Adopting a pragmatic approach that takes all parties' concerns seriously, Shaffer sketches out how existing rules might be adapted, amended, or supplemented to create an "interface," a mechanism for managing expectations, airing disagreements, limiting unnecessary harm or collateral damage, and most of all, restoring trust. In an era of rising uncertainty about existing international institutions, Shaffer expresses faith in the power of international law. The participants in this symposium all share Shaffer's faith, even as they critique particular aspects of his proposal. In their common effort to find a basis for trust between the United States, China, and the rest of the world through institutions, all might be seen as part of a common project Shaffer would likely endorse.

The current plight of the WTO is an abject lesson in the ways legal rules rely for success on unspoken, shared expectations about their use, application, and function. An institution like the WTO reflects a series of settlements over time between its various members, negotiated understandings about their relationships to one another that are committed to paper in only very limited ways. Members have expectations about outcomes—how the rules will foster development, increase prosperity, improve the lives of their citizens, or maintain or enhance their position in the world. Those expectations are bound up with expectations of application—expectations about which policies the members are agreeing to discipline and which they are not. Expectations about the scope of activity covered by a trade agreement — the space left for social policy, public investment, national security, unilateral safeguards—are all part of the settlement(s) embodied by the WTO, even as they are left unwritten in the space between the lines of agreement text. So long as the WTO agreements seem to be applied in such a way as to embody those expectations, recourse to the agreements' provisions can be a source of trust in the relations between states. Recourse to the agreements is recourse to members' shared understandings.

But with technological and geopolitical shifts have come shifts in members' expectations. Changes in the technologies of production and transportation have shifted expectations about who will benefit from trade agreements. Changes in information technologies have shifted expectations about the line between economics and security. Impacts on the environment are shifting expectations about the meaning of prosperity and welfare.

* Gabriel M. Wilner/UGA Foundation Professor in International Law, University of Georgia School of Law.

${ }^{1}$ Gregory Shaffer, Governing the Interface of U.S.-China Trade Relations, 115 AJIL 622 (2021).

(C) Harlan Grant Cohen 2022. Published by Cambridge University Press on behalf of The American Society of International law. This is an Open Access article, distributed under the terms of the Creative Commons Attribution licence (http://creativecommons.org/ licenses/by/4.0/), which permits unrestricted re-use, distribution, and reproduction in any medium, provided the original work is 
And changed fortunes have shifted expectations about the global pecking order-who is, and who will remain, on top. These changes have shifted expectations about the agreements' applications: From subsidies to safeguards, export controls to sanctions, labor rights to the environment, disagreements abound about the types of policies that lie beyond the scope of the agreements and those covered by them, the policies covered by exceptions or not, the types of government interventions that are in keeping with the spirit of the agreements and the types that violate them. Without shared expectations and understandings, recourse to the agreements becomes a source not of trust, but mistrust - fuel for finger-pointing about unfair, opportunistic, or discriminatory interpretations, if not outright violations.

A notable theme of all the symposium contributions here is the importance of "trust" in finding a way forward. And while the term "trust" does not appear much at all in "Governing the Interface of U.S.-China Trade Relations," restoring it is a key implicit theme of Shaffer's intervention. Shaffer recognizes how fraying expectations have fueled U.S. and Chinese disagreements, turning recourse to WTO rules from a source of trust to a source of strain. Reciprocal accusations of violation are met with reciprocal recourse to self-help, feeding a vicious cycle whose effects on third parties only serve to grow the circle of mistrust, recrimination, and attempted punishment or defense.

Breaking the cycle, for Shaffer, requires a different approach to international law rules. Less a form of contract or governance, in Shaffer's account, the rules become a type of interface. The model he adopts and develops, borrowed in part from the U.S.-China Trade Policy Working Group, ${ }^{2}$ creates four categories of behaviors: (1) those that are simply forbidden; (2) those subject to bilateral or plurilateral negotiation; (3) permitted proportionate unilateral adjustments; and (4) those subject to multilateral discipline to avoid spillovers to third parties. Shaffer then demonstrates how these four "buckets" might apply across three "dimensions" of the U.S.-China relationship: economic policy, geopolitical or national security concerns, and normative/rights considerations. While Shaffer works through the details of how this framework might apply to specific, current policy issues, he recognizes that the lines between these buckets and dimensions will remain uncertain and indeterminate.

For Shaffer, trust between the United States, China, and others will be restored by recognizing the ways expectations are changing, not by ignoring them. His approach would recognize room for disagreements and loosen some constraints over policy, but within a framework of rules that can discipline third-party impacts and disproportionate responses while channeling disagreements into fora for discussion. The four buckets and their application across the three dimensions provide less a formal solution to all disputes — a rubric to be applied — than a framework for dialogue, ground rules for "ongoing exchange." 3 In these ways, institutions like the WTO can be adapted to respond to new realities and expectations.

Shaffer, as a pragmatist, recognizes that using this sort of model will require work. Each of the participants in the symposium, highlighting both the depth of current mistrust and very different expectations about existing institutions, suggest how hard that work will be.

For Robert Howse of New York University School of Law, trust remains the central concern. ${ }^{4}$ Howse agrees with Shaffer's approach generally and with the need for more trade policy pluralism specifically. What worries him is whether trust between the United States and China is already too low to support such a framework. Howse observes that both parties have seeded doubts about their respective commitments to the rule of international law. Recent examples of cooperation between the two provide hope that trust can be rebuilt, but both sides may need to invest in trust-building measures before a framework like Shaffer's can be successful. Howse also

\footnotetext{
2 The U.S.-China Trade Policy Working Group Joint Statement, US-China Trade Relations: A Way Forward (2019).

${ }^{3}$ Shaffer, supra note 1 , at 623.

${ }^{4}$ Robert Howse, The Limits of the WTO, 116 AJIL UnBound 41 (2022).
} 
questions the centrality of the W'TO to Shaffer's scheme, wondering if other negotiating fora, whether established organizations like the International Monetary Fund or ad hoc negotiating groups, might be better situated to tackle issues such as cryptocurrencies, investment screening, labor, or environmental standards.

Henry Gao of Singapore Management University asks how China might respond to Shaffer's proposal, and trust again emerges as key. ${ }^{5}$ For China, Gao explains, trust must be built on a foundation of non-discrimination, reciprocity, and respect. Reform efforts that seem to target Chinese practices specifically or to demand more than China has agreed to will bring to mind "unequal treaties" of the past and will, as such, be met skeptically. Working within agreements that have already been made can ground trust and make new agreements possible.

Jingyuan Zhou of Chongqing University School of Law also notes China's differentiation between its explicit W'TO commitments and demands by others to go beyond them and she worries that some of the reform efforts outlined by Shaffer might be seen as part of the latter. ${ }^{6}$ If a framework like Shaffer's is to be successful, "empathetic consideration" of each party's policy priorities, domestic and international, will be necessary. ${ }^{7}$ Zhou also helpfully widens the lens to bring other states, corporations, and international organizations back into view. Any framework adopted by China and the United States can only be effective if it makes space for the roles each of these actors play in economic policy.

Kristen Hopewell of the University of British Columbia adopts the perspective of these "other" actors, moving them from the margins of Shaffer's account back to the center of the frame. ${ }^{8}$ Focusing on China and the United States alone, as Shaffer does, obscures the ways that both of these states have taken unilateral actions that violate or undermine multilateral rules, weaponizing their trade policies to bend other states to their will. For the 162 other WTO members, granting China and the United States more flexibility only feeds the beasts. Restoring trust in the multilateral system - restoring the trust of these other members-requires a renewed commitment to the rule of international law: rules that apply equally to all states and that can be applied equally by all states.

To the credit of his overall project described in this article, Shaffer would likely take all of these critiques on board. His commitment to the open framework described in "Governing the Interface" is a commitment to working through these issues on an ongoing basis. And to the commenters' credit, they seem ready to be part of that dialogue. Constructing the types of conversations Shaffer's model demands will be hard work for all. The contributors to this symposium, myself included, all agree that such work is vastly preferable to slouching toward conflict.

${ }^{5}$ Henry Gao, Trail or Trap? How to Deal with China in the WTO and Beyond, 116 AJIL UnBound 46 (2022).

${ }^{6}$ Jingyuan Zhou, Managing the U.S.-China Relationship in Three (and Three Alternative) Dimensions, 116 AJIL UnBound 52 (2022).

${ }^{7}$ Id. at 52 .

${ }^{8}$ Kristen Hopewell, Beyond U.S.-China Rivalry: Rule Breaking, Economic Coercion and the Weaponization of Trade, 116 AJIL UNBOUND 58 (2022). 